\title{
TRANSITION TOWARDS SUSTAINABLE ECONOMY IN SERBIA - LESSONS FROM DENMARK
}

\author{
Ilija Rajakovićr ${ }^{3}$
}

Originalni naučni rad

doi: $10.5937 / \mathrm{OdrRaz} 2102041 \mathrm{R}$

UDK: 338.1:502.131.1(497.11:489)

$330.342(497.11)$

\section{Abstract}

Sustainable development represents one of the key items on the agenda of governments across the globe. In parallel, numerous important acts on sustainable development have been adopted on both international and national levels, proclaiming ambitious targets on building fossilfuel-free economies, greenhouse gas emission reductions, and environmental protection. However, some countries, particularly the Scandinavian region, significantly lead when it comes to the fulfilment of sustainable development targets, hence being a useful example for other countries to follow. On the other side, Serbia, a developing Southeast European country aiming to become an EU member state, is still at the early phase of transition towards a greener economy. Therefore, in this study, a comparative analysis between Serbia and Denmark has been conducted in the fields of clean energy production, sustainable manufacturing, and investments in green technology, to derive some useful lessons that can be applied to Serbia. Results suggest that, opposite to Serbia, broader inclusion of different stakeholder groups was implemented in Denmark, thereby ensuring decentralisation and democratisation of the whole process. Exactly in these areas could be found points for further improvements in Serbia, related to the wider political debate and stakeholders' inclusion, regulatory changes, decentralisation of energy sector, and broader involvement of financial institutions.

Key words: sustainable development, sustainable economy, renewable energy, optimised manufacturing, sustainable finance, UN Sustainable Development Goals.

13 Doctoral student Singidunum University Belgrade, Republic of Serbia e-mail: ilijarajakovic@yahoo.com 


\section{Introduction}

Economies on the global level are facing numerous challenges nowadays. As a dominant political and economic system in the world, capitalism in its current form has been showing various limitations over the past several decades, while future industrial development will have to be aligned with the principles of sustainable development. In that direction, sustainable development represents one of the critical topics on the agendas of governments worldwide. Countries across the globe have achieved different levels of success in the transition towards more sustainable economies, with the Scandinavian countries often being recognised as leaders. Moreover, Denmark has been widely praised as a highly successful country, recognised as a positive example for other countries to follow. On the other side, Serbia is still at the early stage of implementation of sustainable development principles, significantly lagging behind the developed countries of the EU. However, aiming to become a member state of the EU, Serbia will need to accelerate its path toward a greener economy, as well as to keep in line with the EU standards [1].

Following the mentioned circumstances, this study analysed the current status of sustainable development in Denmark and Serbia by conducting a comparative analysis of three important aspects - clean energy, sustainable manufacturing, and investments in green technologies. Sustainable development represents a highly complex process within every country, consisting of many different areas. Therefore, in this study, three mentioned areas were selected and recognised as immensely important for the overall transition towards the green economy. Selected topics are an indispensable part of the UN Sustainable Development Goals Agenda, particularly depicted in 'Affordable and Clean Energy' (goal 7), 'Industry, Innovation and Infrastructure' (goal 9), 'Responsible Consumption and Production' (goal 12), 'Climate Action' (goal 13), as well as 'Partnership for the Goals' (goal 17). Accordingly, the main goal of this study was to understand and derive positive practices from Denmark, which can serve as useful points for further improvements in Serbia. To this end, significant room has been given to the potential role of the public sector and government, as well as to the role of financial institutions operating on the domestic market. 
The main results from the analysis suggest that Denmark holds an advanced position among the EU countries when it comes to the green economy achievements. This is especially due to the long-term commitment of both political structures and society, characterised by providing room for public debates, stakeholders' involvement, community initiatives, continuous policy improvements, decentralisation of the overall process, active participation of the financial sector, and the importance of public-private partnerships. As a result, Denmark is on track with the ambitious goals proclaimed, being particularly successful in renewable energy production. On the other side, as a result of intertwined internal and external challenges, consistent lack of political will, weak public debate and exclusion of key stakeholder groups, and general lack of interest from financial institutions, Serbia is failing to meet proclaimed targets. Therefore, the primary areas of improvement should be the inclusion of various interested groups and the wider public debate, regulatory improvements, and adoption of several strategic documents, decentralisation of the energy sector, as well as a more decisive participation of financial institutions. Domestic policymakers and government are holding the key role for this to be achieved.

The rest of the paper is structured as follows: Second part explains the methodology used for the purpose of this study. The third part is related to the theoretical background of the research, specifically in terms of various concepts used in literature and public discourse. In the fourth part are presented the main results obtained through the analysis. The fifth part focuses on the discussion on the results obtained, so as to the possible policy implications for Serbia. In the final part, the main conclusions of the analysis are listed.

\section{Methodology}

A substantial review of the literature relevant to the field of research has been conducted for this study.

The scope of the search included sources related to the three categories examined within the study- clean energy, optimised manufacturing, and investments in green technologies. Furthermore, the search included the literature existing on the three different levels important for the studyliterature existing on the national levels of Denmark and Serbia, 
documents adopted within the European Union level, and acts adopted on the global level, particularly related to the United Nations agreements.

Various databases regarding the EU documents and regulations, UN acts on sustainable development, databases on regulations in Serbia and Denmark, as well as Google Scholar, ScienceDirect, and Scopus have been used when conducting the research. Key terms for the search within various databases were related to the concepts of sustainable development, CSR, ESG criteria, sustainable finance, optimised manufacturing, circular economy, renewable energy, energy efficiency and energy savings, but were not limited to this.

\section{Theoretical Background}

Gaining significant interest by both scholars and practitioners during the 1970s, sustainable development has gone through numerous evolving phases over the past several decades [2]. Among the many possible definitions, this concept can be understood as balancing between environmental, social, and economic aspects within the decision-making process, therefore ensuring the stability of the economy and environment for future generations $[2,3]$. As an indispensable part of sustainable development, important regulatory acts have been adopted in different parts of the world, where the United Nations infrastructure is primarily mirrored in the UN Sustainable Development Goals 2030, and the Paris Agreement on Climate Change as key global acts. In order to actively engage in global goals, European Union incorporated ideas and values from mentioned acts within the wide scope of policies, particularly reflected in 'The European Green Deal' [4], while the similar act in the United States represents 'The Green New Deal'. In like manner, government representatives in Serbia also mentioned a program named 'Serbia 2025' within the media conferences. However, an official document has not been adopted yet.

On this road towards global sustainable development, numerous supporting concepts have been introduced, often being used interchangeably in everyday discourse. As a highly important concept related to sustainable development, Corporate Social Responsibility (CSR) represents the introduction of different social and stakeholders' interests in a company's everyday business decisions [5]. Additionally, 
CSR is also referred to as the involvement of Environmental, Social and Governance (ESG) criteria during investment, management, and financial decision processes in companies [6]. Furthermore, CSR is also often connected to sustainable, responsible, and impact (SRI) investing, or investing in socially responsible companies [6].

Internationally adopted acts on climate and sustainable development emphasize the importance of sufficient finance provided for these matters. Although significant amounts should be provided by public sectors, private financial institutions are recognized as a key force. In that sense, sustainable finance as a concept became one of the central topics for financial sectors nowadays. This concept describes the consideration of ESG criteria during the investment decision process in the financial sector, while the main goal is achieving larger investments in sustainable economic ventures in the long run [7]. Evidently, while discussing sustainable development, a necessary matter to be considered is the financing of sustainable actions and projects. Therefore, United Nations Environment Programme Finance Initiative (UNEP FI) has been created to focus on joining the private financial sector to the UN infrastructure, in order to mobilize banks, insurance companies, and investors to impact sustainable development [8]. On the EU level, this was followed by the broad number of acts accepted, such as the EU Action Plan on sustainable finance and EU Taxonomy for sustainable activities [7, 9].

Important space in this study has been given to the concepts of renewable energy, energy efficiency, and energy savings, all being the indispensable part of documents such as the UN SDG 2030 Agenda, European Green Deal, and nationally adopted regulations in Serbia and Denmark. For the sake of clarification, renewable energy is related to the power generated from the naturally repetitive, persistent sources, occurring within the local environments, such as solar radiation, wind, biomass, hydro sources, and geothermal heat [10]. On the other hand, energy efficiency stands for the decreased usage of energy while producing a maintained amount of output, occurring on economic, industrial, sectoral, and individual levels $[11,12]$. Understandably, this term is often used together with energy savings, both having the goal to reduce energy consumption. As final consequences of these three concepts are recognised reduction of greenhouse gas emissions, 
environmental protection, increased competitiveness of the economy, and creation of new jobs [11].

Finally, globally analysed, manufacturing takes a significant stake of overall carbon emission and natural resource usage [13]. Therefore, sustainable or green manufacturing represents another important aspect of sustainable development, particularly analysed in this study. This term could be understood as the transition of a company's internal processes to the more optimised processes, oriented to stakeholders, and energy and resources saving and aiming to minimize negative effects of production on the environment [14]. Additionally, sustainable manufacturing stands for the production of high-quality products, while at the same time companies manage to cut the resources usage, being devoted to using more sustainable resources. In relation to the stakeholders' importance, the position of employees, customers, and communities where the company operates is crucial for sustainable manufacturing [15]. Another concept linked to shifts within production represents the circular economy, in which recycling, reuse, and reduction represent some of the key motives [16]. Although often being difficult to encompass, for the purpose of this study circular economy is understood as the maximization of linear nature-societynature energy and materials flow within production, by utilisation of renewable energy, cascading-energy flaws and cyclical material flows, the definition proposed by Korhonen et al. (2018) [17]. Establishing the circular economy is a highly important topic on the EU agenda, being a part of the European Green Deal and corresponding Circular Economy Action Plan, while Denmark also introduced a National strategy for Circular Economy. Serbia did not adopt any strategic document on this matter yet, while some initial research and roadmaps have been introduced.

\section{Results}

Countries across the globe are facing a demanding journey to reach declared targets on sustainable development, mostly related to the levels of greenhouse gas emissions, the share of renewable energy supply, and energy savings. In regard to mentioned areas, Denmark is commonly considered a highly successful country. On the other side, Serbia is still at the early stage in the transition towards a greener 
economy, and although some important steps have been made, there are still numerous issues to be tackled with. Below are presented the main results from the analysis regarding clean energy, sustainable manufacturing, and investments in green energy technologies.

\section{Road towards sustainability in Denmark}

Historical circumstances and lessons from the past events were important for Denmark to undertake a decisive journey towards sustainable development. Different authors often describe Danish strategy as a peculiar combination of top-down and bottom-up approaches. This implies that one part of the initiatives have been proposed by the civil sector, which was followed by the government with further initiatives, primarily in the form of incentives [18]. As a result of long-term efforts, this country continuously records progress in different sustainability parameters, depicted in the increased capacities of renewable energy, significant energy savings, improved energy efficiency, and reduction of greenhouse emissions both from energy and manufacturing sectors, being the leader among the EU countries $[19,20,21]$. In this way, Denmark has created a strong base to proclaim ambitious goals on environment protection and renewable energy. More precisely, Denmark strives to create a system in which energy production for electricity and heating purposes will be completely generated through renewable sources by 2035, while the whole energy production will completely come from renewable sources by $2050[18,20]$. In addition, according to the Climate act, Denmark declared $70 \%$ of greenhouse gas emission cuts by 2030, in comparison to 1990 [22].

\section{Clean energy}

The oil crisis from the 1970s triggered significant changes in the energy supplies across Europe. Before the crisis, many European countries were fully dependent on fossil fuels, whereas Denmark highly necessitated the import of foreign oil and gas [23]. However, in the aftermath of the crisis, Denmark decided to establish efficient energy supplies, opting for renewable energy as the main source. This happened contrary to the neighbouring countries, which primarily decided to construct nuclear plants as the main alternative [23]. Hence, the energy system in Denmark was constructed in a way that electricity 
is dominantly generated by wind farms and more recently by solar power, while the waste and biofuels are used for heating purposes [20, 23]. As a result of appropriate decisions, around $30 \%$ of total consumed energy comes from renewable sources today, while $50 \%$ of electricity is generated from wind and solar sources [24]. Moreover, district heating leads with around 59\% of used energy from renewable sources in 2017 [25]. Importantly, turning the energy sector to renewable sources is the most responsible for greenhouse gas emission cuts in Denmark over the last three decades [21]. Significant room in the clean energy transition has been given to energy savings and energy efficiency. These aspects represent an important part of the 2012-2020 Energy Agreement, proclaiming the $8 \%$ cut of energy consumption by 2020 compared to 2010 [26]. For this to be achieved, a joint effort of public institutions, private companies and citizens has been made. Statistics show that energy savings were largely introduced in all the major sectors, particularly industry, real estate, and manufacturing [19, 27].

A great example of Danish success in the transition towards clean energy on the local level represents the case of Sams $\varnothing$, a 3700inhabitants island in the Kattegat sea. At the end of the 1990s, the local community, in cooperation with the government and different municipality bodies, got engaged in the transformation of electricity generation and district heating systems, by building onshore and offshore wind turbines, solar collectors, and biomass boilers. As a result, today Sams $\varnothing$ island represents a self-sufficient energy system, where electricity production overpasses its consumption, and the $\mathrm{CO} 2$ footprint is a negative 15 tons per inhabitant [28]. Sams $\varnothing$ transformation is primarily characterised by the significant involvement of the local population in the project from the very beginning, with great enthusiasm and green values deeply incorporated within the community. Regular public discussions were highly present, so as the democratic approach in which preferences and interests of the locals were of the greatest importance. In that direction, different stakeholders created a consortium led by Sams $\varnothing$ Energy Academy, a meeting place for partnerships of energy projects in Sams $\varnothing$. The consortium members also include the municipality of Sams $\varnothing$, local energy agency, local development office, municipality-owned energy company and Sams $\varnothing$ citizens [29]. As the outcome, $90 \%$ of windmills are owned by local 
people, while a specific ownership mix of private owners, local cooperatives, investor groups, and municipality government has been created. This was helped by the ideation of the financing process, with the low threshold to join and the possibility to pay off in instalments. Therefore, not only has this created sustainable and environmentally oriented energy solutions which slowly started spreading out to sustainable transportation and agriculture, but it also opened a space for locals to achieve financial gains. The whole project created a significant number of new jobs within the island, while also becoming a great tourist attraction.

Establishing a stable energy system that highly counts on renewable sources did not come overnight. Rather it was the result of appropriate decisions made over the last several decades. First of all, the government introduced various supporting schemes, which encouraged interested parties on the local level to participate and invest. The outcome is that around $20 \%$ of renewable energy plants for electricity production are currently owned by local population cooperatives, local farmers, and local landowners [23]. Moreover, in the heating sector, around $83 \%$ of the distribution is owned by consumers or municipalities [23]. Secondly, state authorities widely accepted ideas proposed by local institutions and organisations as an important stakeholder group. The activities of high schools, universities, working groups, and NGOs were highly helpful in creating various initiatives, commonly known as grassroot initiatives (GI) [23]. Furthermore, it was the society initiatives that further help encourage the government to engage in organising sustainable energy communities in Denmark, which resulted in the creation of simultaneous top-down and bottom-up approach [18]. With the help of educational and local institutions, public debate on renewable energy has been opened, while communities became familiar with the potentials and importance of renewable energy in terms of its reliability and sufficiency [18, 23]. As a third aspect for success, Denmark is known for its tradition of small entrepreneurs and cooperative ownership type, whereas the already existing infrastructure proved particularly important when the renewable projects arrived at the agenda [18, 23]. Fourthly, Denmark introduced a strong regulatory framework for sustainable development in a broader sense, for both renewable energy and energy efficiency alike. This regulatory infrastructure secured the proper implementation 
of policies, keeping the track of the achievements and transparency, while the pivotal act currently represents the Climate act, with corresponding sectoral strategies and yearly follow-ups on achievements. Fifthly, the prerequisite for all of this was the strong political will that existed in crucial moments of transition towards a cleaner energy system. In Denmark, green parties were highly influential during the 1980s and 1990s, the pivotal years for creating a strong base for renewable energy development [20, 23]. Finally, some studies suggest that the sole allocation of energy sources within the whole energy sector led to success. In other words, one of the crucial aspects was the process of decentralisation of power generation, which especially took place over the 1980s and 1990s, therefore making a peculiar energy mix [20].

\section{Sustainable manufacturing}

Sustainable manufacturing went hand in hand with renewable energy efforts in Denmark, and it is the field in which this country has been also recognised as a highly successful example. Similarly, the road towards more green and optimized manufacturing in Denmark is not a recent process. Starting with the 1980s, optimized manufacturing became a key aspect of a broader process named 'Greening the industry' in Denmark [30]. In that manner, over the past several decades, Denmark invested significant funds in a transition towards a more sustainable industry [31]. Even more, domestic private companies continuously invest large funds in research and development for technology improvements prerequisite for optimized production. R\&D investments in the manufacturing sector solely amounted DKK 23 billion in 2018, which represents $56 \%$ of whole industry R\&D investments [31]. Consequently, manufacturing represents a pivotal part of the industry in terms of the production of green products in Denmark, amounting to DKK 131 billion in 2018, or 57\% of green products in the whole industry [31]. Denmark also records a continuous decline in greenhouse gas emissions over the last decade, while manufacturing stands for around $9 \%$ of overall gas emissions, and the decline over the same period amounted $27 \%$, together with a decline of $9 \%$ in energy consumption [31]. Additionally, the Danish economy is also known for the circular sustainable production approach, meaning that companies are connected in a loop of resources exchange, where 
one company's waste is used as another company's resource [32]. A practical example of this approach represents Kalundborg symbiosis, a partnership on a local level between 11 public and private companies, aiming to reduce waste [33]. The process of the circular economy represents a very important concept on the EU agenda, being one of the key parts of the European Green Deal, whereas a new action plan has been adopted in 2020. Finally, implementing sustainable manufacturing is not only the action from companies and public institutions in Denmark. Consumers also significantly changed their behaviours and habits. According to the report on manufacturing in Denmark from 2016, customers continuously expect from manufacturers the sound response to the growing environmental standards. Moreover, according to the same report, domestic manufacturers perceive this market trend as a great growth opportunity [34].

Once again, listed achievements arrived as a result of the decades-long efforts and appropriate actions. Firstly, significant regulatory changes were introduced on state, municipality, and private companies' levels, while circular economy takes an important place in Danish industry regulations [30]. Together with this, starting in 2009, Denmark introduced mandatory reporting on CSR as a non-financial part of annual reports for large companies. Secondly, the government introduced support schemes for the implementation of green technologies as an additional tool [30]. Regarding this, an important role has been given to private-public collaboration, pictured in projects such as Kalundborg symbiosis. In that direction, the decisiveness of domestic private companies was highly contributing to the road towards sustainability (i.e., in gas emission reduction) [31]. Thirdly, similar to the renewable energy process, also in sustainable manufacturing significant room has been given to the environmental experts, advanced technology engineers, and state representatives on environmental protection, creating an important arena for public debate [30]. Lastly, an important aspect in Denmark was the disposition of domestic industry, where small and medium enterprises (SME) take the largest part [30]. Strategic initiatives did not exclusively come from the large corporations, but from the Danish SME sector as well [35]. Consequently, SMEs managed to improve their reputation in society, while at the same time also introducing significant cost reductions which made their production more efficient [35]. 
Investments in green energy technologies

Similar to the previous two parts, sustainable finance in Denmark is the area in which a high commitment to the public debates, exchange of opinions, and stakeholders' inclusion can be recognised. In addition, a certain kind of investment mix in sustainable projects which includes various finance sources, such as government, private financial institutions, communities, and local authorities is present in Denmark [18].

In order to achieve declared targets, domestic sectors are engaging in specific types of public-private collaborations [36]. This type of partnership has been successfully implemented in various sectors such as healthcare and infrastructure, and Denmark continues using the model in financing ESG oriented projects. Some of the main institutions involved in this field are Innovation Fund Denmark, the Danish Growth Fund, and the Danish Green Investment Fund [36]. For instance, the Danish Green Investment Fund, which is positioned as an independent state entity, provides loans for projects in the areas of environmental savings, renewable energy sources, and resource efficiency [37].

Despite being a country with just a 5.8 million population, Denmark has a diversified financial sector that consists of 76 banks and mortgage credit institutions, with 7 domestically-owned banks holding a leading position. Such a decentralized structure helps to allocate the capital more toward small and medium companies and support smaller-scale ESG projects than would be the case with a highly concentrated financial system. Also important is the role that pension funds and insurance companies have in the domestic financial market [38, 39]. Danish banks, investment funds and pension funds have been already ideating and offering a variety of sustainability products over the past decade to their investors [36]. Regarding the financial institutions' role, pension funds in Denmark are some of the major financial market players who turned to the investments in areas such as renewable energy, significantly moving their focus from investments in fossil fuel projects [40].

Over the past decade, Denmark expanded to the international arena, by providing the finance for various sustainable projects, especially within 
developing countries. For instance, there is a considerable involvement of the Export Credit Agency of Denmark which offers financing to foreign buyers for purchase Danish green solutions. These measures directly help domestic companies expand their global reach and position themselves as leaders in the quickly developing field of sustainable economy solution providers. This financial institution has provided significant funds in terms of issuing guarantees for fields such as bioenergy, solar energy water, energy efficiency, and many others [40]. Another example of private-public collaboration represents the Danish Climate Investment Fund and the Danish Climate Investment Fund for Developing countries, also offering large funds for climaterelated projects from abroad. Those institutions provided significant finance in loans for areas such as climate, agrobusiness, food, production and infrastructure [40, 41, 42]. In this segment, an important role in this context is given to several ministries within the government, especially the Ministry of Foreign Affairs, the Ministry of Climate, Energy and Utilities, and the Ministry of Environment.

\section{Road towards sustainability in Serbia}

Compared to the case of Denmark, the Serbian journey towards a greener economy is starkly different. Following the collapse of the communist regime at the beginning of the 1990s, Serbia entered into the long and demanding process of transition towards a market economy. Privatisation and the establishment of democratic institutions have been the key aspects of this process, but neither has been successfully managed or completed by 2021. On the international level, Serbia also faced significant challenges. During the 1990s, Serbia was involved in armed conflicts with several neighbouring countries, culminating in the NATO bombing in 1999, all having severely harmful effects on the domestic economy. Therefore, dealing simultaneously with different internal and external challenges, sustainable development was not of interest for the political structures in Serbia over the last three decades. As a consequence, Serbia today significantly lags behind other European countries when it comes to a sustainable economy and environmental protection.

However, aiming to become a member state of the EU and to fulfill internationally accepted targets, Serbia will have to undertake decisive steps in order to reach environmental standards declared within the EU 
framework [1]. This matter represents a highly important aspect of the EU negotiation process, being encompassed by several chapters, particularly chapter 15 (energetics) and chapter 27 (environmental protection), none of them being opened yet. Nevertheless, over the last two decades, Serbia managed to achieve some important steps, mostly related to the regulatory changes. Strongly relying on the EU framework, Serbia adopted several important laws and by-law acts on environmental protection, energy efficiency, and renewable energy, where specifically important place takes the Strategy for Sustainable Development [1]. Their implementation on the ground, on the other hand has been missing.

\section{Clean energy}

Energy represents one of the main sectors of the Serbian economy, accounting for around $10 \%$ of its GDP. Its main segments include coal mines, oil and natural gas industry, electricity system, decentralised municipal district heating, and industrial energy [43, 44]. The energy sector in Serbia is characterised as highly centralised, with around $98 \%$ of total electricity being produced by the state-owned company Elektroprivreda Srbije (EPS). This company predominantly utilises lignite coal for electricity production, which is a fossil fuel characterised as extremely pollutive. As a consequence, electricity and heat production represent key greenhouse gas emission sectors in Serbia, whereas around $80 \%$ of total $\mathrm{CO} 2$ emissions come from the energy sector [45]. Moreover, Serbia significantly overpasses CO2 emissions when compared to its GDP, particularly from 2013 onwards [45]. Analysing official acts and statements, EPS proclaims devotion to renewable sources' improvements. Hydro-power plants stand as the main renewable energy source in EPS operations, accounting for around $21 \%$ of total production [46, 47]. However, when excluding hydro-power generation, the share of renewable energy production becomes quite marginal in the overall sector [47, 48]. Moreover, although sustainability represents one of the pivotal goals proclaimed by the domestic government and EPS, large investments are still directed towards the coal-fired plants in Serbia [47].

When it comes to the sustainability of the energy system in Serbia, renewable energy production is still in the early phase [49]. The renewable energy mix in Serbia consists of solar, wind, water, 
geothermal, and biomass energy production, whereas experts put the emphasis on biomass as source with the greatest potential in the future. The goal set for 2020 was that $27 \%$ of total use of energy comes from renewable energy sources [50, 51, 52]. Moreover, the official target was that $30 \%$ of energy mix by 2020 to be from renewable energy. Both mentioned targets were in accordance with EU regulations, especially EU Renewable Energy Directive [45]. However, the share of renewable energy usage amounted around $21 \%$ in 2018 , while the mentioned targets were not met in 2020 [47, 53, 54]. Also, renewable energy sources are largely related to hydropower, while all the major hydropower plants are already existing for decades. Regarding the new initiatives, companies like EPS are focusing on mini-hydropower plants, ventures being largely criticised as harmful for environment [47]. Adding to that, the ownership structure and the legal aspects of building mini-hydropower plants are highly controversial, and there has been a major backlash against them by the population. Regarding the other renewable energy sources, wind and solar power plants are at a very early stage, and EPS has significant room for improvements in this area. In order to attract potential investors, the Serbian government introduced various incentives for renewable energy producers, primarily by offering beneficial prices for the purchase of energy produced by renewable sources. This matter is currently subject of policy changes, since new measures are expected to take place during the 2021.

Even though the parliament adopted law on Efficient use of Energy in 2013, Serbia is still described as country with low level of energy efficiency, together with very large energy consumption, mostly due to the high electricity usage [44]. Inefficiency in energy usage represents one of the key problems in domestic energy sector, while some indicators imply continuous decrease of energy efficiency in Serbia [55]. Furthermore, studies suggest that energy consumption increased by $30 \%$ over the past two decades. Additionally, the largest increase in energy usage is observed in households and industry [55].

\section{Sustainable manufacturing}

Domestic manufacturing companies have been passing through the long and slow process of privatisation over the last three decades. Unfortunately, different studies suggest that privatisation process in 
Serbia did not bring advancements in domestic production, export potential of companies, nor achieved desired industry structure [56]. Furthermore, domestic companies are in significantly worse conditions in comparison to the other former communist economies, especially in terms of research and development, technological improvements, marketing management, and level of investments [56]. Therefore, it should not come as a surprise that the Serbian industry continuously records negative patterns such as energy consumption increase, a simultaneous decrease of energy efficiency index and large greenhouse gas emissions [55]. Over the last two decades, domestic regulators introduced regulatory acts on mandatory energy management for domestic manufacturing companies, but the official data on its success has not been publicly declared by responsible bodies.

When it comes to energy consumption, materials consumption, resource productivity and recycling of the waste, Serbian industry significantly lags behind developed EU countries [57]. Evident is the need for more unified action which will gather a greater number of companies from the manufacturing sector that can form mutually beneficial partnerships and collaboration as was mentioned in the example of Kalundbord symbiosis. In that sense, an important topic for Serbia should be the circular economy, the approach being highly promoted within the EU. Even though Serbia currently does not have any official strategic document on the circular economy, studies and roadmaps on this matter have been initiated $[57,58]$.

Finally, as mentioned throughout this paper, sustainable manufacturing is highly linked to the sphere of CSR within the companies. However, this kind of non-financial reporting is still at the early stage in Serbia, whereas multinational companies and large domestic corporations significantly lead in this matter. Moreover, although CSR reporting is mandatory for the EU large companies, Serbia did not introduce a similar policy into the domestic framework. Certain studies imply that state bodies should be more committed to the promotion of CSR, so as to adopt additional regulatory acts which will further shape and clarify this matter, but which will also involve economic incentives for the companies which operate in accordance with ESG criteria [59]. 


\section{Investments in green energy technologies}

Financial sector in Serbia is largely dominated by banks. Over the past two decades, evident is consolidation trend within the banking sector, resulting in 25 banks currently operating in the market. Banks are majorly foreign-owned, and exactly the foreign banks represent key market players in terms of asset size and number of clients. On the other side, capital market is severely underdeveloped, being prevailed by government debt securities [60]. In addition, pension funds that operate on Serbian market are focused on the investments of risk-free solutions such as government bonds. Furthermore, tradition of private equity and venture capital funds does not exist in Serbia. Other market players, such as state-owned development financial institutions which should have been at the forefront of the movement, also did not make any significant steps in providing investments in green technologies. Finally, tradition of public-private partnership for environmental matter in Serbia is not long nor deep, with the first one occurring in 2019 as a part of the Vinča environmental infrastructure [61].

In circumstances like these, domestic companies and retail clients are largely oriented toward banks when it comes to financing sustainable projects such as renewable energy, energy savings and optimising production. For this purpose, numerous domestic banks did place customized products on the market. Analysing the web presentations of the banks in Serbia, it is observable that all leading banks offer projects of financing green technologies to corporate clients, SMEs, and retail clients. However, this is majorly a part of the collaboration and supporting schemes by various international financial institutions and programs, while independent initiatives are more than rare. This implies that banks on the Serbian market are not ready to enter solely into green projects, often characterised as highly risky [62].

Regarding the leading international institutions, EBRD supports various green projects in Serbia, such as city transport renewal, water infrastructure, renewable energy sources, as well as approving the credit lines to banks on the domestic market. EBRD mostly collaborates with municipalities and state representatives, but this institution highly emphasizes the importance of the activation of private entities [63]. KfW is another foreign financial institution that is largely involved in financing green technologies in Serbia, also cooperating 
with domestic banks to provide finance for renewable energy, energy efficiency and infrastructure. Additionally, IFC as a part of World Bank has an important role in the Serbian marketplace, being particularly focused on CSR improvement within Serbian companies and banks. Furthermore, EIB is a highly contributing institution, taking a part in various initiatives for funding green technologies in Serbia. Mentioned institutions also were devoted in the creation of various group initiatives such as the Western Balkans Investment Framework and Green for Growth Fund. Finally, IPA funds provided by the EU are also a very important source of finance for green technologies in Serbia [64].

\section{Discussion and policy implications}

Serbia will have to undertake more decisive steps in the process towards the sustainable economy soon. Understandably, developed EU countries like Denmark have a decades-long experience of changes, and while the whole process cannot be copied, some important lessons could be derived. Several starting points for Serbia will be presented below, with the overall idea of policy implication focused on the wider inclusion of stakeholder groups, democratisation and decentralisation of the process.

Firstly, firm resolution and devotion to the cause from political structures in Denmark have been visible from the early stages, and at the crucial points of the journey. In parallel, significant room has been given to the public debate and exchange of opinions, while the grassroot initiatives proved to have a high potential [23]. On the other side, Serbia has been passing through severe political shifts over the last three decades, and sustainable development was not the topic of primary interest for decision-makers. This must be a starting point for improvements, where domestic political structures should be devoted to support different stakeholders' initiatives and ensuring public debates on important topics. At the moment, both of these are heavily missing. This particularly since the participation of society and citizens in policy making represents basic rights guaranteed and implied through the constitution and different laws in Serbia [65].

Secondly, although several laws on environmental protection, renewable energy and energy efficiency have been adopted, there is 
still significant room for improvements within the regulatory framework, especially by adopting sectorial strategic documents. Policymakers should undertake more decisive steps towards the circular economy by creating clear strategic documents which could open up the large potentials of circular economy ideas related to new job positions and increased competitiveness of the Serbian economy $[57,58]$. Serbia is a highly centralised country, with a strong disconnect between state level and rural regions. Thus, policy changes should be focused on supporting underdeveloped regions and less populated municipalities, in which circular economy and renewable energy ventures could introduce job opportunities for young professionals willing to return. Another regulatory effort should be devoted to the mandatory CSR reporting with clear monitoring infrastructure, recognised as non-financial reporting of large companies, accepted on the EU level, but still not incorporated in Serbian framework. Additionally, efforts should be focused on the incentives for the SME, one of the pivotal sectors within the domestic economy.

Thirdly, important changes should be implemented within the energy sector. When analysing the Denmark case, it is clear that the energy system is strongly decentralised, where the ownership structure significantly involves local farmers and landlords, local cooperatives, final consumers and municipalities. On the other hand, Serbian energy sector, electricity in particular, is dominated by monopolized stateowned company as a key market player. Even though small hydropower plants did show up as new market participants, their effect on the environment, and therefore overall positive impact, is still subject to a heated debate, while their investors are commonly linked to the political structures. To this end, the democratisation of access to the energy market, decentralisation, and transparent operating process should be the main goal for policy makers. For this purpose, the Sams $\varnothing$ case could be a useful guide, where the financing of the project was set up in such way as to enable locals to directly invest in the building of wind-turbines, therefore democratising the process and linking individual's financial and environmental interests.

Finally, flaws within the domestic financial sector imply significant challenges in obtaining finance for sustainable projects. In the system in which the capital market is severely undeveloped, without activities 
from private equity and venture capital funds and weak initiatives from pension funds, banks represent the only solution for both retail and corporate clients. However, a general problem in the financing projects exist due to the insufficient commercial attractiveness of sustainable projects and high risks [62]. Therefore, domestic regulators should be devoted to creating fully functional capital market and marketing it to wider public and global financial investors, as well as both encouraging and backing up private financial institutions in the carefully selected projects that would be used as a catalyst for expansion of sustainable development projects.

\section{Conclusion}

This study conducted the comparative analysis of transition towards the sustainable economy in Denmark and Serbia, considering three important aspects of sustainable development- clean energy, sustainable manufacturing and investments in green technologies. According to the results obtained, Denmark holds an advanced position among the EU countries when it comes to the share of renewable sources in the energy sector, optimisation of manufacturing processes, the consequent reduction of greenhouse gas emissions, and creation of peculiar finance mix for sustainable projects, particularly relying on public-private partnerships. This arrived as a result of long-term devotion to sustainable development principles, appropriate regulatory framework, the commitment of political structures, the inclusion of different stakeholders, decentralisation and democratisation of the key processes. On the other side, Serbia experienced a significantly different journey, while the whole process has been burdened with numerous internal and external challenges. Consequently, Serbia is still at the early phase of the green economy transition, with significant room for potential improvements. In that direction, results from the analysis suggest that in the upcoming years, domestic policymakers must create a space for debates and inclusion of different stakeholders, regulatory changes on strategic documents and monitoring processes should be presented, decentralisation of energy sector should be introduced, so as the wider engagement of both private and public financial institutions. In short, wider inclusion of different players should be established in the years to come, therefore creating the peculiar alignment between individual and community interests, profit- 
oriented interests, and the overall environmental protection and sustainable development.

\section{Literature}

[1] Zdravkovic, Dusan, and Snezana Radukic. "Institutional framework for sustainable development in Serbia." Montenegrin Journal of Economics 8.3 (2012): 27.

[2] Tomislav, Klarin. "The concept of sustainable development: From its beginning to the contemporary issues." Zagreb International Review of Economics \& Business 21.1 (2018): 67-94. [3] Emas, Rachel. "The concept of sustainable development: definition and defining principles." Brieffor GSDR 2015 (2015). [4] "A European Green Deal" European Commision https://ec.europa.eu/info/strategy/priorities-2019-2024/europeangreen-deal_en Accessed 22 Apr. 2021.

[5] Khan, Muhammad Tariq, et al. "Corporate social responsibility (CSR)-definition, concepts and scope." Universal Journal of Management and Social Sciences 2.7 (2012): 41-52.

[6] Liang, Hao, and Luc Renneboog. "Corporate social responsibility and sustainable finance: A review of the literature." European Corporate Governance Institute-Finance Working Paper 701 (2020).

[7] "Sustainable Finance" European Commision https://ec.europa.eu/info/business-economy-euro/banking-andfinance/sustainable-finance_en Accessed 22 Apr. 2021.

[8] "About UNEP FI" UNEP FI https://www.unepfi.org/about/ Accessed 19 Apr. 2021.

[9] "Explaining the EU Action Plan for financing sustainable growth" $\quad P R I \quad$ https://www.unpri.org/sustainable-financialsystem/explaining-the-eu-action-plan-for-financing-sustainablegrowth/3000.article\#: :text=On\%207\%20March\%202018\%2C\%2 0the,Commission\%20on\%2031\%20January\%202018 Accessed 18 Apr. 2021.

[10] Twidell, John, and Tony Weir. Renewable energy resources. Routledge, 2015.

[11] Patterson, Murray G. "What is energy efficiency?: Concepts, indicators and methodological issues." Energy policy 24.5 (1996): 377-390. 
[12] "Understanding energy efficiency" Erbach, Gregor, European Parliamentary

Research

Service

https://www.europarl.europa.eu/RegData/etudes/BRIE/2015/56836 1/EPRS_BRI(2015)568361_EN.pdf Accessed 9 May 2021.

[13] Ngai, E. W. T., et al. "Energy and utility management maturity model for sustainable manufacturing process." International Journal of Production Economics 146.2 (2013): 453-464.

[14] "Sustainable Manufacturing" EPA https://www.epa.gov/sustainability/sustainable-manufacturing Accesses 26 Apr. 2021.

[15] Machado, Carla Gonçalves, Mats Peter Winroth, and Elias Hans Dener Ribeiro da Silva. "Sustainable manufacturing in Industry 4.0: an emerging research agenda." International Journal of Production Research 58.5 (2020): 1462-1484.

[16] Kirchherr, Julian, Denise Reike, and Marko Hekkert. "Conceptualizing the circular economy: An analysis of 114 definitions." Resources, conservation and recycling 127 (2017): 221-232.

[17] Korhonen, Jouni, Antero Honkasalo, and Jyri Seppälä. "Circular economy: the concept and its limitations." Ecological economics 143 (2018): 37-46.

[18] Heaslip, Eimear, Gabriel J. Costello, and John Lohan. "Assessing good-practice frameworks for the development of sustainable energy communities in Europe: Lessons from Denmark and Ireland." Journal of Sustainable Development of Energy, Water and Environment Systems 4.3 (2016): 307-319.

[19] "Denmark's engagement in energy efficiency" Danish Ministry of Energy, Utilities and Climate, 2015 file:///Users/localadmin/Downloads/Onepager_k5_2.pdf Accessed 8 May 2021.

[20] Pinson, Pierre, et al. "Towards fully renewable energy systems: Experience and trends in Denmark." CSEE journal of power and energy systems 3.1 (2017): 26-35.

[21] "Greenhouse gasses" Danish Energy Agency https://ens.dk/en/our-responsibilities/energy-climatepolitics/greenhousegasses\#: :text=Denmark\%20has\%20reduced $\% 20$ emissions $\% 20$ sin 
ce,dropped $\% 20$ with\%20approximately\%2020\%20pct. Accessed 8 May 2021.

[22] "Climate action in Denmark" Simões, Henrique, M. and G. Victoria, European Parliamentary Research Service, 2021 https://www.europarl.europa.eu/RegData/etudes/BRIE/2021/67910 6/EPRS_BRI(2021)679106_EN.pdf Accessed 8 May 2021.

[23] Kooij, Henk-Jan, et al. "Between grassroots and treetops: Community power and institutional dependence in the renewable energy sector in Denmark, Sweden and the Netherlands." Energy Research \& Social Science 37 (2018): 52-64.

[24] "Pioneers in clean energy" Denmark.dk https://denmark.dk/innovation-and-design/clean-

energy\#: :text=Clean\%20energy\%20is\%20a\%20Danish,already\% 20comes\%20from\%20renewable\%20sources. Accessed 8 May 2021.

[25] "District Energy in Denmark" Euroheat \& Power, 2019 https://www.euroheat.org/knowledge-hub/district-energy-denmark/ Accessed 8 May 2021.

[26] "Danish Energy Agreement for 2012-2020" International Energy Agency, 2020. https://www.iea.org/policies/606-danishenergy-agreement-for-2012-2020 Accessed 12 Apr. 2021.

[27] "Energy Savings", Danish Energy Agency https://ens.dk/en/our-responsibilities/energy-savings Accessed 9 Apr. 2021.

[28]

"Samsø"

EnezGreen, 2021

https://www.enezgreen.com/en/samso/ Accessed 17 May 2021. [29] "Best practice: $100 \%$ renewable energy island" Renewables Networking Platform https://www.renewablesnetworking.eu/documents/DK-Samso.pdf Accessed 17 May 2021. [30] Remmen, Arne. "Greening of Danish industry-Changes in concepts and policies." Technology Analysis \& Strategic Management 13.1 (2001): 53-69.

[31] "The Danish business sector and the sustainable development goals", $\quad$ Statistics Denmark, 2021 https://www.dst.dk/Site/Dst/Udgivelser/GetPubFile.aspx?id=44794 \&sid=erhmaluk Accessed 28 Apr. 2021. 
[32] "Circular sustainable production" Copenhagen Capacity https://www.copcap.com/invest-in-greater-copenhagen/investmentopportunities/sustainable-production Accessed 20 Apr. 2021.

[33] "Explore Kalundborg symbiosis" Kalundborg symbiosis http://www.symbiosis.dk/en/ Accessed 28 Apr. 2021.

[34] "Danish manufacturing - winning in the next decade" McKinsey\&Company, 2016 https://pure.au.dk/portal/files/98323703/Danish_Manufacturing_Fu 11_Report.pdf Accessed 28 Apr. 2021.

[35] Reyes - Rodríguez, Juan Felipe, John P. Ulhøi, and Henning Madsen. "Corporate environmental sustainability in Danish SMEs: A longitudinal study of motivators, initiatives, and strategic effects." Corporate Social Responsibility and Environmental Management 23.4 (2016): 193-212.

[36] "The role of Financial Sector in the Sustainable Transition: Forum for Sustainable Finance 20 Recommendations to Finance Denmark" Forum for Sustainable Finance, 2019 https://www.epaper.dk/finansdanmark/forum-for-sustainablefinance-20-recommendations-to-finance-denmark/ Accessed 30 Apr. 2021.

[37] About the Danish Green Investment Fund" Danmarks Grønne Investeringsfond https://gronfond.dk/en/om-fonden/ Accessed 30 Apr. 2021.

[38] "Denmark" Eurosif http://www.eurosif.org/sri-study2016/denmark/ Accessed 5 Apr. 2020.

[39] "Denmark - Financial sector assessment program" International Monetary Fund, 2020 file:///Users/localadmin/Downloads/1DNKEA2020002.pdf

Accessed 29 Apr. 2021.

[40] "Financing the Green Transition" State of Green, 2016 https://stateofgreen.com/en/uploads/2016/05/Financing-the-GreenTransition.pdf Accessed 30 Apr. 2021.

[41] "Danida Sustainable Infrastructure Finance" Investment Fund for Developing Countries https://www.ifu.dk/en/danidasustainable-infrastructure-finance-en/ Accessed 22 Apr. 2021. [42] "Danish SDG Investment Fund" Investment Fund for Developing Countries https://www.ifu.dk/en/danish-sdginvestment-fund-2/ Accessed 22 Apr. 2021. 
[43] Đajić, Nenad, and M. Mesarović. "LONG TERM OUTLOOK OF ENERGY SECTOR IN SERBIA." 17. FORUM: EUROPA, HRVATSKA I REGIJA 2030. GODINE 17th FORUM: EUROPE, REGION AND CROATIA IN. Vol. 2030. 2012.

[44] "Energy Sector Serbia" Serbia Energy https://serbiaenergy.eu/energy-sector-serbia/ Accessed 4 May 2021.

[45] "Greenhouse Gas Emissions in Serbia" USAID, 2017 https://www.climatelinks.org/sites/default/files/asset/document/201 7_GHG\%20Emissions\%20Factsheet\%20Serbia.pdf Accessed 4 May 2021.

[46] "Energetski sektor" Foreign Investors Council, 2020 https://fic.org.rs/wp-content/uploads/2020/11/08-2-Energetskisektor.pdf Accessed 4 May 2021.

[47] "Serbia's Renewable Energy Commitments" Lewis, Miles, European Policy Centre https://cep.org.rs/en/blogs/serbiasrenewable-energy-commitments/ Accessed 4 May 2021.

[48] Stipic, S., et al. "Potentials of renewable energy sources in the Republic of Serbia with a detailed review of the exploitation of geothermal resources in the autonomous province of Vojvodina." Sustainable Use of Geothermal Energy: Research into Injection and Water Treatment (2012): 91-121.

[49] Golusin, Mirjana, Zdravko Tesic, and Aleksandar Ostojic. "The analysis of the renewable energy production sector in Serbia." Renewable and sustainable energy reviews 14.5 (2010): 1477-1483.

[50] Dragović, Njegoš M., Milovan D. Vuković, and Dejan T. Riznić. "Potentials and prospects for implementation of renewable energy sources in Serbia." Thermal Science 23.5 Part B (2019): 2895-2907.

[51] "National Renewable Energy Action Plan of the Republic of Serbia" Ministry of Energy, Development and Environmental Protection, 2013 https://www.mre.gov.rs/sites/default/files/2021/03/national_renewa ble_energy_action_plan_of_the _republic_of_serbia_28_june_2013 .pdf Accessed 4 May 2021.

[52] "Obnovljivi izvori energije" Energetski portal https://www.energetskiportal.rs/obnovljivi-izvori-energije/ Accessed 4 May 2021. 
[53] "Serbia to double share of renewable energy, reach $40 \%$ by 2040 - minister" Balkan Green Energy News, 2021 https://balkangreenenergynews.com/serbia-to-double-share-ofrenewable-energy-reach-40-by-2040-minister/ Accessed 9 May 2021.

[54] "The energy sector in Serbia" Bankwatch Network https://bankwatch.org/beyond-coal/the-energy-sector-in-serbia

Accessed 5 May 2021.

[55] "Serbia profile" Odyssee-Mure https://www.odysseemure.eu/publications/efficiency-trends-policies-

profiles/serbia.html\#: :text=According\%20to\%20EU\%20obligatio ns\%20Republic,by\%20Government\%20in\%20late\%202016

Accessed 4 May 2021.

[56] Stošić, Ivan, Ivana Domazet, and Hasan Hanić. "Effects of privatization and restructuring on manufacturing industry: the evidence from Serbia." Metalurgia internaţional 18.7 (2013): 7782.

[57] "Resource efficiency and circular economy in Europe - even more from less. An overview of policies, approaches and targets of Serbia in 2018" ETC/WMGE, European Environment Agency, 2018 https://www.eionet.europa.eu/etcs/etc-wmge/products/bcountry-profile-serbia_finalised.pdf Accessed 5 May 2021.

[58] "Roadmap for circular economy in Serbia" Ministry of Environmental Protection, Republic of Serbia, 2020 https://www.rs.undp.org/content/serbia/en/home/library/mdg/road map-for-circular-economy-in-serbia.html Accessed 5 May 2021. [59] "Društveno odgovorno poslivanje za sve" Unija poslodavaca Srbije, $\quad 2015 \quad$ https://www.poslodavci.rs/wpcontent/uploads/2015/11/studija-o-dopu-u-srbiji.pdf Accessed 5 May 2021.

[60] Minović, Jelena, and Vlastimir Vuković. "Analysis of the Serbian Capital Market." Economic Analysis 46.1-2 (2013): 1-11. [61] "EBRD invests record EUR516 million in Serbia in 2019" Vlajcic, Bojana. European Bank for Reconstruction and Development https://www.ebrd.com/news/2020/ebrd-investsrecord-516-million-in-serbia-in-2019.html Accessed 6 May 2021. [62] Sergi, Bruno S., et al. "Public-Private Partnerships as a Mechanism of Financing Sustainable Development." Financing 
Sustainable Development. Palgrave Macmillan, Cham, 2019. 313339.

[63] "EBRD and the Green Economy Transition: a strategy for sustainable investments in Serbia" Balkan Green Energy News, 2017 https://balkangreenenergynews.com/green-economytransition-in-serbia/ Accessed 6 May 2021.

[64] "Finansiranje projekata" Green Energy http://zelenaenergija.pks.rs/ZelenaEnergija.aspx $? \mathrm{id}=25 \& \mathrm{p}=7 \&$ Accessed 3 May 2021.

[65] "Demokratija pred izazovom- kako javnost učestvuje u stvaranju politike životne sredine" Beogradska otvorena škola, 2014 https://www.bos.rs/du/uploaded/PRINT_Consensus.pdf Accessed 10 May 2021. 


\title{
ТРАНЗИЦИЈА КА ОДРЖИВОЈ ЕКОНОМИЈЕ У СРБИЈИ - ЛЕКЦИЈЕ ИЗ ДАНСКЕ
}

\author{
Илија Рајаковић ${ }^{14}$
}

\begin{abstract}
Резиме
Одрживи развој представља једну од кључних тачака на дневном реду влада широм света. Паралелно са тим, усвојени су бројни важни акти о одрживом развоју како на међународном тако и на националном нивоу, који прокламују амбичиозне циљеве за изградюу привреде без фосилних горива, смањење емисије гасова стаклене баште и заштиту животне средине. Међутим, неке земье, посебно скандинавски регион, значајно предњаче када је у питану испуьавање циьвева одрживог развоја, па су стога користан пример за друге земље. С друге стране, Србија, земља југоисточне Европе у развоју која жели да постане чланица ЕУ, још увек је у раној фази транзииије ка зеленијој економији. Стога је у овој студији спроведена компаративна анализа између Србије $u$ Данске у области производње чисте енергије, одрживе производње и улагања у зелену технологију, како би се извукле неке корисне лекиије које се могу применити на Србију. Резултати показују да је, за разлику од Србије, у Данској спроведено шире укључивање различитих група заинтересованих страна, чиме је обезбеђена децентрализачија и демократизација целог проиеса. Управо у овим областима могу се наћи тачке за даља побољшања у Србији, која се односе на ширу политичку дебату и укључивање заинтересованих страна, регулаторне промене, децентрализачију енергетског сектора и шире укьучиване финансијских институција.
\end{abstract}

Кључне речи: одрживи развој, одржива економија, обновљива енергија, оптимизована производња, одрживе финансије, ичиљеви одрживог развоја УН.

Datum prijema / Date of arrival: 24.08.2021.

Datum prihvatanja / Accepted date: 11.10.2021.

14 Student Doktorskih studija Univerzitet Singidunum Beograd, R. Srbija e-mail: ilijarajakovic@yahoo.com 